\title{
New Voices on the Harlem Renaissance: Essays on Race, Gender,and Literary Discourse
}

\author{
Australia Tarver \\ Paula Barnes \\ Emily J. Orlando \\ Fairfield University, eorlando@fairfield.edu
}

Follow this and additional works at: https://digitalcommons.fairfield.edu/english-books

Copyright 2006 Farleigh Dickinson University Press

Content archived here with permission from the copyright holder.

\section{Recommended Citation}

Tarver, Australia; Barnes, Paula; and Orlando, Emily J., "New Voices on the Harlem Renaissance: Essays on Race, Gender,and Literary Discourse" (2006). English Faculty Book Gallery. 5.

https://digitalcommons.fairfield.edu/english-books/5

This item has been accepted for inclusion in DigitalCommons@Fairfield by an authorized administrator of DigitalCommons@Fairfield. It is brought to you by DigitalCommons@Fairfield with permission from the rightsholder(s) and is protected by copyright and/or related rights. You are free to use this item in any way that is permitted by the copyright and related rights legislation that applies to your use. For other uses, you need to obtain permission from the rights-holder(s) directly, unless additional rights are indicated by a Creative Commons license in the record and/or on the work itself. For more information, please contact digitalcommons@fairfield.edu. 


\title{
"Feminine Calibans" and "Dark Madonnas of the Grave": The Imaging of Black Women in the New Negro Renaissance
}

\author{
EMILY J. ORLANDO
}

\begin{abstract}
You decide that something is wrong with a world that stifles and chokes; that cuts off and stunts; hedging in, pressing down on eyes, ears and throat. Somehow all wrong. ... Why do they see a colored woman only as a gross collection of desires, all uncontrolled, reaching out for their Apollos and the Quasimodos with avid indiscrimination? ... Why are you a feminine Caliban craving to pass for Ariel?
\end{abstract}

-Marita Bonner, "On Being Young-a Woman-and Colored"

Can you not hear us?...

Can you not see us? ...

We yearn to hear

The beauty of truth

From your lips.

-Mae Cowdery, "The Young Voice Cries: To Alice Dunbar Nelson"

As you know, men are apt to idolize or fear that which they cannot understand, especially if it be a woman.

-Jean Toomer, Cane

THE DECEMBER 1925 NUMBER OF OPPORTUNITY: JOURNAL OF NEGRO Life sports on its cover Aaron Douglas's striking rendering of what came to be recognized as "The New Negro": a man's silhouette-bold, directed, strong-with a cityscape, dwarfed in comparison, set off to the right (figure 1). ${ }^{1}$ This December issue promoted Alain Locke's newly-released, much-awaited anthology, The New Negro: An Interpretation, an extension of the March issue of Survey Graphic. ${ }^{2}$ A full-page advertisement celebrates the "first complete book on and by The Negro." The selective list of contributors reads like a "Who's Who" of what often is referred to as the Harlem Renaissance: Locke, Albert C. Barnes, William S. Braithwaite, Countee Cullen, Arthur A. 


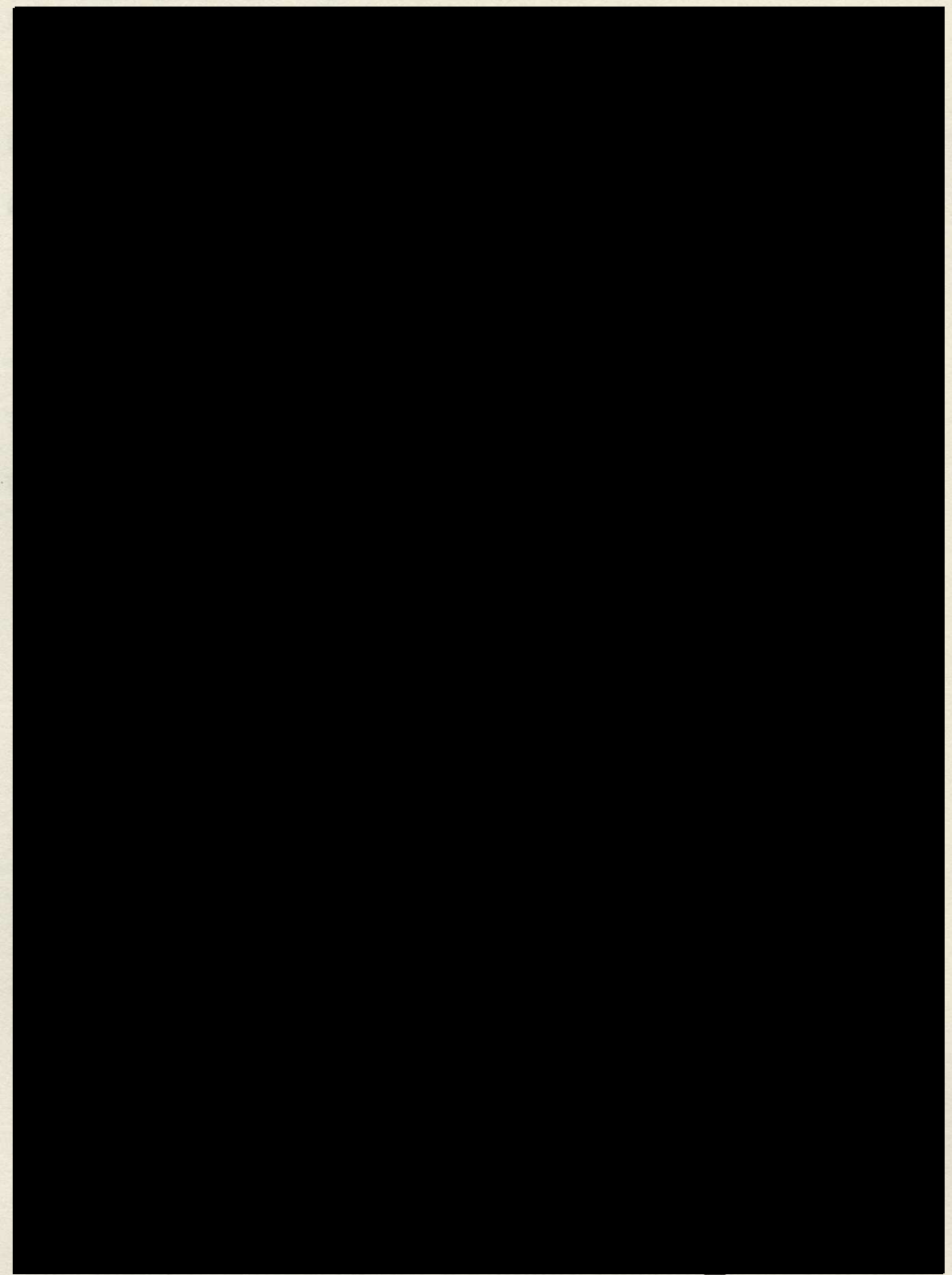

Fig. 1. Aaron Douglas, cover of December 1925 Opportunity, Journal of Negro Life. Photo courtesy of the National Urban League. 
Schomburg, and other emerging voices of the African American race. While the text acknowledges Zora Neale Hurston and Jessie Redmon Fauset for contributing "fiction" to the issue, it is pointedly ironic that the additional women writers participating in this project are classed under the heading "Other Articles," with "other," of course, functioning as the pivotal term.

Locke's prefatory essay, titled "The New Negro," recognizes "a renewed and keen curiosity" directed at the once-othered Negro: "the Negro is being carefully studied, not just talked about and discussed. In art and letters, instead of being wholly caricatured, he is being seriously portrayed and painted" (Locke, 9). Locke's foreword to the volume is articulated in a kind of aesthetic discourse: "portraiture," "the national canvas," and "selfportraiture" all figure in the opening paragraph, underscoring the author's interest in the "imaging" of African Americans in art and literature. ${ }^{3}$ Further, Locke's rhetoric makes it clear this "New Negro" is decidedly gendered male; Locke repeatedly refers to "the Negro himself," elsewhere announcing that "The Negro Takes His Place in American Art" (emphasis mine). "Poet laureate" of the Renaissance Langston Hughes, in "The Negro Artist and the Racial Mountain" (1926), reinscribes the gender of this New Negro artist: he looks forward to the dawning of a "truly great Negro artist, the one who is not afraid to be himself" (Hughes, in Lewis, 92). Hughes celebrates the New Negro and "his art," "his race," "his heritage," alluding to several black artists, most of them male (Hughes, 92). I want to turn attention to how the female New Negro (perhaps, in Locke's lexicon, an oxymoron) is portrayed and painted in this artistically rich-and allegedly revisionary-period. ${ }^{4}$

Like Locke, the women artists of the Harlem Renaissance concern themselves with distinguishing what he calls "the fact" from "the fiction" (Locke, 9). They analogously are invested in redrawing the distorted images to which Locke points our attention: "Up to the present one may adequately describe the Negro's 'inner objectives' as an attempt to repair a damaged group psychology and reshape a warped social perspective" (Locke, 10). To a certain extent, the black women artists of this period in turn are responding to the damaging ways in which they are imaged in such groundbreaking works as Locke's anthology.

The focus of this study is the imaging of African American women during the Harlem Renaissance or, to use Locke's terminology, the "Negro Renaissance." In my treatment of the sexual politics of representation, I will analyze and juxtapose the ways 
in which black women are depicted by male and female writers of the period. For the most part, these portraits were printed in the movement's most prominent literary vehicles-e.g., Crisis and Opportunity - and thus were made available to a wide audience. I will explore how black women are presented in selected works by some of the key (male) figures of the period: Jean Toomer's Cane; Alain Locke's New Negro; poetry by Countee Cullen, James Weldon Johnson, Langston Hughes, and others. To acknowledge a dialogue between the male artists and their female colleagues, my discussion will address literary portraits of women in a variety of woman-authored texts, especially: poetry by Georgia Douglas Johnson and Gwendolyn Bennett; fiction by Nella Larsen; and nonfiction by Marita Bonner and Elise Johnson McDougald. ${ }^{5}$ Though I do not wish to suggest here that all male writers of the Harlem Renaissance portrayed black females in damaging ways-nor, for that matter, to imply that all female writers of the Harlem Renaissance were innocent of stereotyping their male counterparts-this essay nevertheless foregrounds some of the most prominent male-authored and femaleauthored images of the black woman in this Renaissance, which contrast most starkly with one another around questions of female agency. Because, as I described above, the New Negro man is so frequently described as a fearless actor on a world stage, we must ask whether and where the New Negro woman is afforded a similar literary existence. This essay asserts that it is predominantly black female writers, in contradistinction to many male writers, who gave life to the image of an active and fearless New Negro woman.

Although my primary focus will be literary portraits of women, I recognize a need for us to turn our attention to iconographic images from an age that spoke so provocatively to the eyes. ${ }^{6}$ To that end, I will discuss renderings of women in the visual art of Winold Reiss and Aaron Douglas (as two representative male artists) and that of Gwendolyn Bennett and Lois Mailou Jones (as representative female artists). ${ }^{7}$ Having taken as my point of departure Locke's anthology, I will follow its editor's lead and "carefully study" how the New Negro's female counterpart is "seriously portrayed and painted" in this text. I will examine the various types that are figured, disfigured, and reconfigured in the artwork of the period. In so doing I will work against the outmoded conception that the Harlem or New Negro Renaissance was primarily a male artistic movement, having set 
out to identify how these women artists established for themselves a particularly female artistic agency. ${ }^{8}$

As this essay will illustrate, male writers of the Harlem Renaissance tended to portray women in ways they appropriated from earlier, white male writers. The tropes they most commonly adapted to their own uses include the Madonna, the woman-as-objet d'art, the "feminine Caliban" Ito use Bonner's phrase invoked in my epigraph), and the beautiful corpse. In spite of its revisionary agenda, the movement in fact harkened back to tired, jaded forms. As I will argue, women writers of this artistic movement also imaged black women in their works, and these images can be read as responses to, and rejections of, portrayals of African American women by African American men. I will show that, even in the face of the constricted, stifling ways in which their bodies were represented in this movement, black women managed to carve out a space for their own creativity.

It is abundantly clear from the art of the Harlem Renaissance that an important asset of the New Negro is his pair of "fearless," gazing eyes. The literature of this cultural movement resonates with references to glances and gazes. For instance, Cullen's "To a Brown Girl," published in the poet's first book of verse (1925), speaks of a man's "glance" that is "bold and free" (Cullen, Color, 7). A sonnet by James Edward McCall titled "The New Negro" captures the spirit of the Negro as gazer, beginning as it does with the image of a black man scanning the world with eyes "calm and fearless" (McCall, in Cullen, Caroling Dusk, 34). And while McCall breathes new life into an old literary form, it is relevant to this discussion that the "modern," revised art forms of the Harlem Renaissance-like the sonnet sequences of literary forebears Petrarch, Sidney, Shakespeare, and Dante Rossetti-contained women in very fixed, very limiting roles.

We need only turn to the frontispiece of Locke's anthology to identify one of the roles to which women were assigned in the art of this Renaissance: the archetypal mother. Winold Reiss's "The Brown Madonna," which greets us at the start of The New Negro, appropriates a traditional trope-the Madonna and child. The woman wears the blue of the traditional depictions of the Virgin Mary and her hair modestly frames her forehead and temples as if to mimic the wimple worn by the Virgin. Further, Reiss has framed her shape with shadows that suggest a heavenly glow radiating from her being. Reiss's image is innovative insofar as the Virgin Mary is rendered black ${ }^{9}$ (figure 2). Yet she is not a proud, confident figure: her gaze is diverted; she humbly looks 
Fig. 2. Winold Reiss, "The Brown Madonna," frontispiece to The New Negro, edited by Alain Locke.

down; she seems rather sedate. We see only one of her hands, which is engaged in the act of nurturing: the hand cradles the (presumably) male child; it most certainly does not hold a pen or an artist's brush. Albert Rice's poem "The Black Madonna" replicates this construction of women. Rice's speaker invokes a 
Virgin "[n]ot as the white nations know [her]" but one "swarthy of cheek / and full-lipped as the child races are" (Rice, in Cullen, Caroling Dusk, 177). The Virgin is described as "the Immaculate Maid," a pure woman conceived without sin. So here again the image of the Madonna is revisionist in that she is Africanized-as a gesture of race pride-yet it serves to send a message to black women that the role of self-sacrificing attendant is one of the few available to her. Further, the reference to the Immaculate Conception recalls Christianity's emphasis on the Madonna's reliance upon a male savior for redemption. She is not so very empowered after all.

Georgia Douglas Johnson's "Motherhood" (1922) can be read as a response to the type of images manufactured by Winold Reiss and Albert Rice. ${ }^{10}$ Rather than unquestioningly embrace the role of nurturer, Johnson's startling poem turns the idea of selfless motherhood on its head. The speaker expresses a rather vocal rejection of her role as mother; she is reluctant to give birth and thus expose her "little one" to a world in which "cruelty and $\sin ^{\prime \prime}$ run unchecked:

Don't knock at my door, little child, I cannot let you in,

You do not know the monster men Inhabiting the earth,

Be still, be still, my precious child,

I must not give you birth! (Johnson, in Lewis, 274)

Johnson's speaker, then, renounces the ideal of motherhood and implies her body willingly would interfere with the birth of this child-through abortion or stillbirth-for its own good. The poem reclaims for the black woman a certain degree of agency over her body with its suggestion that childbirth is not a passive endeavor and in fact involves a choice. ${ }^{11}$

If some male writers of the Harlem Renaissance accorded black women some degree of agency-like the Madonna, she can bear and nurture children-they apparently as readily denied it. Appropriating resonant images of women from select literary forbears, these writers portrayed women as objets d' art and as beautiful corpses-sometimes both at once-reducing them to objects of their gazes. Maureen Honey points to the interest these black male writers had in the literary conventions of the British Romantic writers, for 
the Romantics saw art and truth as connected, a viewpoint that echoed [the Harlem Renaissance artists'] own sense that the ills of modern life stemmed from a coarsening of the human spirit due to acquisitive, aggressive domination by a white ruling class. Nature offered an Edenesque alternative to the corrupted, artificial environment created by "progress." (Honey 7)

Cullen, for instance, made clear the inspiration he drew from Keats's verse (e.g., "To John Keats, Poet. At Spring Time"). I would add that the British Romantics were largely men who imaged women in constricting roles. We need only look to Keats and Wordsworth for examples of traditional roles ascribed to women (e.g., Keats's "La Belle Dame sans Merci," "Lamia," and "Eve of St. Agnes"; Wordsworth's "Lucy" poems). So it follows that if Harlem Renaissance authors imitate the Romantics, they in turn mimic their literary predecessors' peculiar habit of disseminating distorted images of women.

Countee Cullen's "A Song of Praise" harkens back even further to the literary conceits of the English Renaissance, specifically those employed by Shakespeare in his sonnets to his "dark lady." Cullen co-opts the tropes of the Elizabethans when he notes that while his "love" is "dark as yours is fair, / Yet lovelier I hold her. . .."12 The speaker here offers up an idealized portrait of the black woman, a lady so delicate her "light" step "does not dent the smoothest moss / Or bend the thinnest grass" ${ }^{\prime}$, her feet are not firmly planted on the earth, suggesting her lack of groundedness. And, in keeping with much of the art produced by male figures of the Harlem Renaissance, the lady remains the object of the man's gaze. In fact, the speaker invites the reader to join him in his objectifying glance:

You-proud-and-to-be-pitied-one,
Gaze on her and despair;
Then seal your lips until the sun
Discovers one as fair.

(Cullen, Color, 4)

So while the speaker asserts and affirms the beauty of his dark lady, he nonetheless conceives of her as an object to be gazed upon.

We might borrow from Cullen the phrase "Dark Madonna of the grave" to describe another popular Harlem Renaissance construction: the black woman as dead object subjected to a male gaze that objectifies and denies agency. By featuring this dead 
woman in his art, the male artist consciously or unconsciously images the black woman as an object robbed of agency. She becomes a passive entity subject to our gaze, as if to echo Edgar Allan Poe's signature claim that the quintessential subject for art is the death of a beautiful woman. As Elisabeth Bronfen has noted in Over Her Dead Body: Death, Femininity and the Aesthetic (1992), "death turns the woman into an object of sightthe dead feminine body comparable to an exhibited art object" (Bronfen, xiii). Bronfen observes that "[t]he image as substitute of a body implies that the body must disappear so that it can again be grasped and yet the distancing and exchange this involves implicates the viewer as well." 13 So as readers and gazers we promote the objectification of the black female body.

Cullen's "A Brown Girl Dead," with its attending image in Color, points the reader's gaze to a dead black woman who also is associated with the Madonna trope, in spite of being identified, in the title, as "Girl": "Dark Madonna of the grave she rests; / Lord Death has found her sweet." The young woman is "lai[d] . . . out in white" for all eyes to consume, suggesting not only Lord Death, but also the viewer, might find her "sweet" (Cullen, Color, 6). Being no longer alive, she lacks the power to return or deflect the hungry gazes of others. Further, the girl is described as an object at the receiving end of the action; for instance, her mother "lay[s] her out in white" and the only "active" verb associated with the girl is in fact passive: she simply "rests." Bronfen's remarks on Dante Gabriel Rossetti's poem "The Portrait" are equally true of Cullen's piece: "Though . . . the cause of the woman's death is a textual ellipsis, the portrait is presented as a metaphorical 'killing' of the woman .... the image, by replacing body with sign[,] negates her presence" (Bronfen, 119). As such, works like Cullen's border on the misogynistic in their interest in killing a woman for aesthetic pleasure and altogether negating her.

The tradition of reproducing dead bodies in art is bound up with history. Philippe Ariès in Images de l'homme devant la mort has noted that during the sixteenth century a new trope entered portrait painting, which peaked in the art and photography of nineteenth-century culture-depictions of men and women just after death, recording the features not only of the subject's life but also of its death (Ariès, in Bronfen, 112). James Van Der Zee's The Harlem Book of the Dead (1978) pays homage to a tradition of photographing dead bodies, male and female, laid out in caskets at funeral parlors. The text gathers together 
many of Van Der Zee's images of this Harlem ritual of honoring the deceased. While The Harlem Book of the Dead depicts both men and women equally, it is worth noting the disproportionate frequency with which women are represented as dead bodies in the art and literature of the period. For instance, an image created by Aaron Douglas for the October 1925 Opportunity cover, titled "The Mulatto," represents a woman as if she were laid out for burial: her eyes are shut and her motionless hands are folded over her breast in the pose of a corpse (figure 3). She is almost of a piece with those works that project the image of "Dark Madonna of the grave." To be sure, Douglas's humble mulatta stands in striking contrast to the New Negro that graced the December cover the same year.

Sterling Brown's "Georgie Grimes" also invokes the figure of the Dark Madonna of the grave, and in this case the text literally and metaphorically kills the woman into art. Brown's poem narrates the story of a man who murdered a woman-apparently his disobedient lover: "Georgie remembers hot words, lies, / The knife, and a pool of blood" (Brown, in Lewis, 235). He likewise recalls the nameless woman's "staring eyes, / With their light gone out for good" (235). So here the male persona's attention is fixed on the female gaze-one that he has extinguished. Her eyes can no longer look. Brown's poem recalls Robert Browning's "My Last Duchess" in its treatment of a man's silencing of an insubordinate woman whose behavior had been the source of his discontent: Georgie consoles himself that "No livin' woman got de right / To do no man dat way" (235). While it is productive to recognize, of course, the important distance between the narrator and Georgie Grimes-the speaker clearly does not celebrate this act of cold-blooded murder-the text nonetheless conjures up the image of a dead woman whose powers of vision and voice have been stripped away. ${ }^{14}$

Marita Bonner lends the name "feminine Caliban" to a female stereotype of the Harlem Renaissance that ostensibly possesses more agency than the Dark Madonna of the grave: a depraved, licentious woman who has surrendered to her sexual appetites and paid the price. Bonner's "On Being Young-a Woman-and Colored (1925)," first printed in The Crisis, laments the damage done by this construction of black women as "a gross collection of desires, all uncontrolled, reaching out for their Apollos and the Quasimodos with avid indiscrimination" (Bonner, 5). Cullen gives to this female type the name "Black Magdalens": 


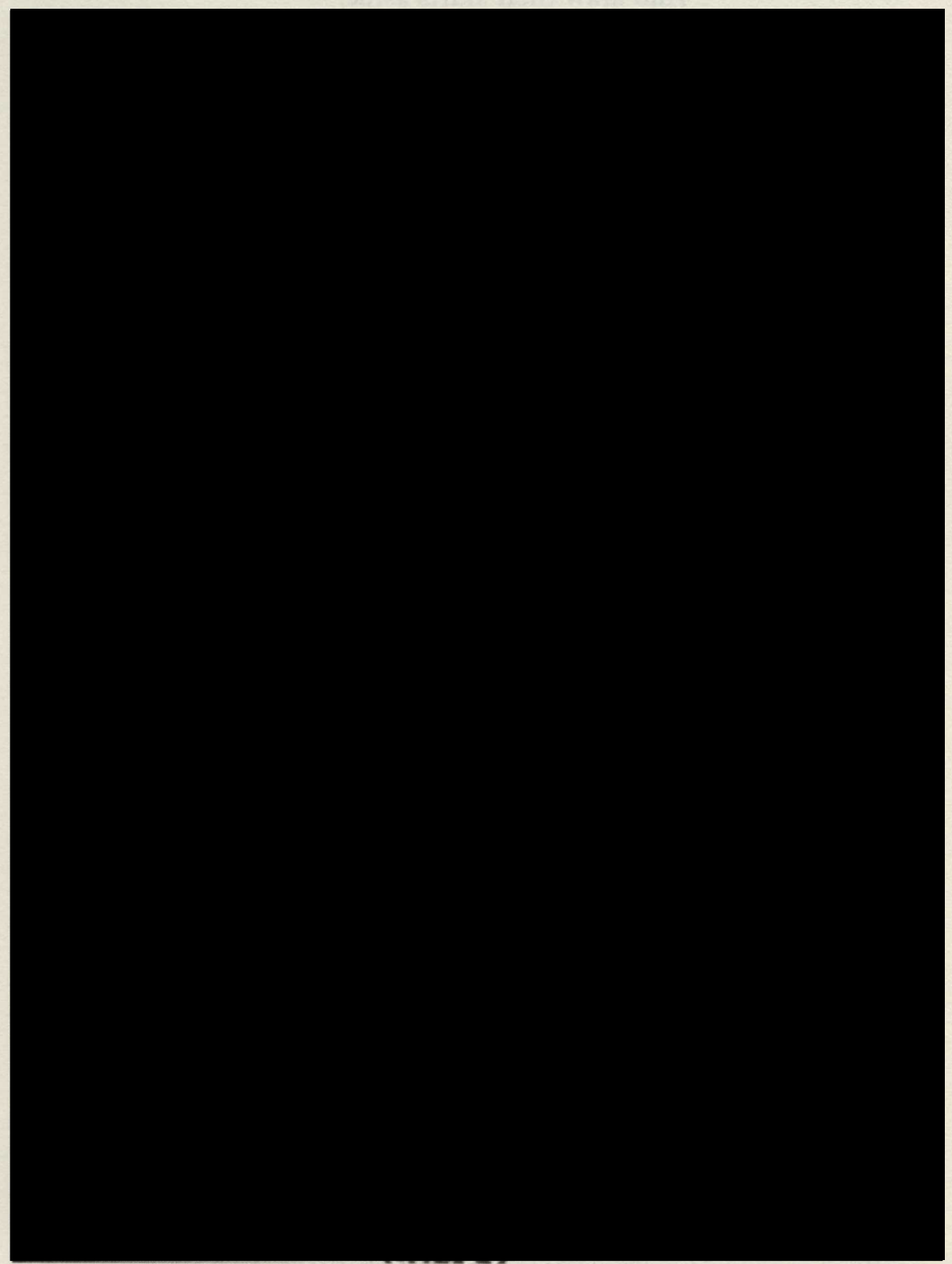

Fig. 3. Aaron Douglas, cover of October 1925 Opportunity, Journal of Negro Life. Photo courtesy of the National Urban League. 
The chaste clean ladies pass them by

And draw their skirts aside,

But Magdalens have a ready laugh.

They wrap their wounds in pride.

(Color, 9)

This poem's formal structure-fairly regular versification, tidy four-quatrain organization, $a b a c$ rhyme scheme-serves to further contain a woman in a fixed role (here, a Mary Magdalen/ fallen woman, the polar opposite of the Virgin Mary).

By now it will be clear that a recurring theme among these female types is youth. Bonner, in her essay, calls attention to the challenges attached to a subjectivity that is young, black, and female. The recurrence of youth among these types raises issues about its importance in women: being young suggests possibilities for procreation, as we have seen in the trope of the Madonna; at the same time it suggests the potential for sexual activity-a behavior that these constructions attempt to contain and suppress. We will see this most clearly in the trope of the feminine Caliban.

Bruce Nugent's meditation "Sahdji," while less formal than Cullen's verse, presents a similarly sexualized woman in its story of the "favorite wife" of an East African tribal chieftain. The piece is almost stream of consciousness, fragmented as it is by ellipses. That a woman is being imaged as an object of the gaze is clear from the first line, which points our attention to "a sketch," drawn by the speaker, of "a little African girl ... delightfully black" (Nugent, in Locke, 113). The narrator offers his own picture of "her beautiful dark body ... rosy black." Sahdji is the object of desire of all the men who encounter her: the male speaker, her aging husband, her husband's son. The woman, then, clearly serves an aesthetic function: to please the eyes. In Locke's The New Negro, "Sahdji" is accompanied by Aaron Douglas's dramatic illustration by the same name (figure 4). Douglas's rendering presents Sahdji as seemingly nude, bejeweled, and painted. His image collaborates in transforming the woman into an object in at least three ways: first, it features only one of Sahdji's hands, which suggests her lack of empowerment; second, it positions an enlarged profile of a male face, off to the right, whose eyes fix Sahdii in its gaze; third, the five oval shapes touching the left side of her body, which resemble eyes, imply all eyes are on Sahdji. ${ }^{15}$ Beside her, the man's head, which resembles the "New Negro" Douglas produced for the December Op- 


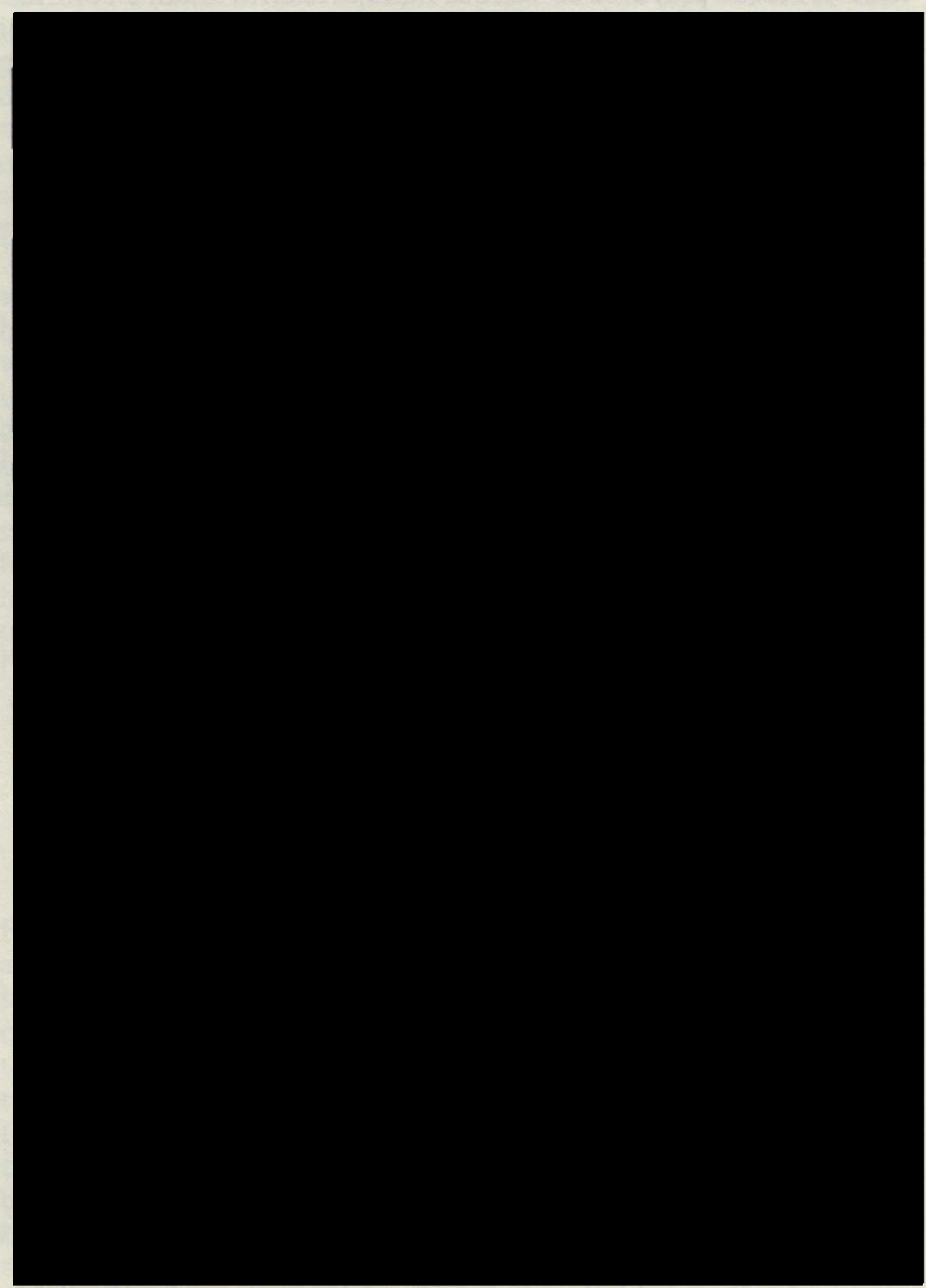

Fig. 4. Aaron Douglas, illustration for "Sahdji" for The New Negro, ed. Alain Locke. 
portunity cover, overshadows all four female figures and its mouth seems prepared to devour Sahdji. Each woman's countenance betrays distress and alarm, as if frantically shooing the man away. Douglas's work, informed by cubism /a distorting, disfiguring medium), collaborates, perhaps unwittingly, with Bruce Nugent's to trap women in quarters that are as confining as they are stifling.

Jean Toomer's revolutionary Cane (1923) similarly makes use of modernist forms ultimately to contain its women. While innovative in its resistance to traditional classifications, marking as it does the literary beginnings of the Harlem Renaissance, the text nonetheless bodies forth images of women that are old, tired, and jaded. Early on in the narrative, Toomer's speaker makes a rather poignant confession: "men are apt to idolize or fear that which they cannot understand, especially if it be a woman" (Toomer, 16). Importantly, Toomer's work occasionally seems to describe, even decry, this phenomenon (without recognizing its own participation in it); for example, in his portrait of Fern, discussed at length below, Toomer observes his protagonist's listless passivity, eerie gaze, and "broken" voice, which suggest a despondency over the dispossession of many black women in rural life. However, certain aspects of his depiction of Fern, as well as the other women of Cane, evidence the profound extent to which he nevertheless participates in a counterproductive imaging of black women. Women are imaged as prototypical feminine Calibans in Toomer's test. His Karintha, for instance, is objectified as a site of male desire. Immediately we are told "[m]en had always wanted her, this Karintha" (3). Much emphasis is placed on Karintha as object of the gaze: in one of the verse interruptions, which describes the woman's "dusk"-like skin, the speaker asks "O cant you see it, ... cant you see it" (4). In fact, the verb "to see" figures prominently in "Karintha" but more often than not the woman finds herself at the receiving end of the visual gesture.

Toomer's Karintha, in fact, is the receiver of all the activity in this segment of Cane; she is figured as entirely inert. Although she has been a mother, even the act of child labor is discounted as if it were for her a passive occurrence: "A child fell out of her womb onto a bed of pine-needles, in the forest" (4). She is almost etherealized; there is nothing human about this labor, which, of course, is diametrically opposed to what we see in Georgia Douglas Johnson's "Motherhood," discussed earlier. And in keeping with the lack of agency we recognize in Karintha, it is 
no surprise we never hear this woman's voice. First, while Karintha's voice is described to us, it is filtered through the intervening male narrator-a gesture we can read as symbolic of the channeling of the female voice in this cultural movement. Second, the fact that the voice is captured in such unpleasing terms- "high-pitched, shrill, [Karintha's voice] would put one's ears to itching" (3)-indicates that Toomer's speaker expects a woman's voice to be as aesthetically pleasing as her appearance, rather than jarring and disruptive.

Toomer's "Fern" - a portrait of an enigmatic, alluring mulatta, which looks back to the sexualized tragic mulatta of days pasthere again the male artist provides a script that casts a passive woman in its starring role. ${ }^{16}$ Fern too is subjected to an objectifying male gaze; the speaker's eyes unabashedly linger up and down the woman's body: "you will know my feeling when I follow the curves of her profile, like mobile rivers, to their common delta" (16). The speaker reads Fern as something of what we might today call a "traffic stopper"-a woman so strikingly beautiful she stops traffic and, reminiscent of the mythic siren, leads to man's destruction. Her link with the siren is more apparent when we hear how unholy is the connection between Fern and the men who have relations with her:

When she was young, a few men took her, but got no joy from it. And then, once done, they felt bound to her ..., felt as though it would take them a lifetime to fulfill an obligation which they could find no name for. They became attached to her, and hungered after finding the barest trace of what she might desire. (16)

Fern remains a porch-bound passive object that the male speaker and the hypothetical male listener/"friend" watch as they ride by on a train: "you'd be most like to see her resting listless-like on the railing of her porch, back propped against a post, head tilted a little forward." (17). Significantly, the male is moving (in train) while the female remains stationary (on porch). Such positioning points to the difference between male as agent (doer of the action) and female as passive construction (object acted upon). The male speaker, in fact, invites the reader to join him in imaging this woman: "picture if you can, this cream-colored solitary girl sitting at a tenement window looking down on the indifferent throngs of Harlem" (16). Fern, of course, is not situated in Harlem but instead is planted-like Karintha-as part of the rural Georgian landscape: "Saw her on the porch, ... eyes 
vaguely focused on the sunset. Saw her face flow into them, the countryside and something that I call God, flowing into them" (19). This woman in a sense becomes part of the land and thus is further imaged as a passive construction, something to be settled, tamed, and appropriated like the wilderness itself, in keeping with an American literary tradition described by Annette Kolodny in The Lay of the Land: Metaphor as Experience in American Life and Letters (1975). Toomer's construction of women looks forward to Langston Hughes's "Nude Young Dancer," which captures an exotic woman as though she were an extension of the jungle:

What jungle tree have you slept under, Midnight dancer of the jazzy hour? What great forest has hung its perfume Like a sweet veil about your bower?

(Hughes, in Locke, 227)

The accompanying illustration by caricaturist Miguel Covarrubias, in Locke's New Negro, contributes to a reading of this woman as provocative and sexually alluring. While this "[d]ark brown girl of the swaying hips" would seem to be liberated in her role as a flapper-and her smile exudes confidence-there is much about her that is contained: her two hands bound together at her side, her hair tucked neatly beneath a cap, the choker encircling her throat, her smallness in relation to the (male) text that frames her. Together these details serve up a picture of a woman disempowered, a woman whose eyes are not sufficiently "bold" to meet the gaze of the spectator. ${ }^{17}$ What Laura Mulvey, in her groundbreaking essay "Visual Pleasure and Narrative Cinema" (1975), says of women translates to Toomer's Fern:

They are being turned all the time into objects of display, to be looked at and gazed at and stared at by men. Yet, in a real sense, women are not there at all. The parade has nothing to do with woman, everything to do with man. The true exhibit is always the phallus. Women are simply the scenery onto which men project their narcissistic fantasies. ${ }^{18}$

Surely, Fern is the scenery onto which men project their desires. As for Fern's own gaze, we are told she has "strange eyes": "[m]en saw her eyes and fooled themselves. Fern's eyes said to them that she was easy." (16). So her eyes-"strange," "weird" as they may be-are less for seeing than for being seen, i.e., ren- 
dered the object of a controlling gaze: "Anyone, of course, could see her, could see her eyes" (320). As in "Karintha," the phrase "See her" is repeated like a refrain throughout Toomer's sketch of Fern. But Fern does, in spite of the speaker, seize control of the gaze: "I held Fern in my arms.... Her eyes, unusually weird and open, held $\mathrm{me}^{\prime \prime}(19)$. And, what is more, her eyes are so engaging they "[h]eld God" (19). Yet, in spite of the power of her captivating gaze, this woman's agency is ultimately relinquished, as the emphasis on Fern as passive object is reinstated by the end of the piece: "I saw her ... saw her on the porch."19 The speaker's continued use of active voice (I saw her) demonstrates his interest in preserving his position as aggressive agent. As Mulvey has noted,

[i]n a world ordered by sexual imbalance, pleasure in looking has been split between active/male and passive/female.... In their traditional exhibitionist role women are simultaneously looked at and displayed, with their appearance coded for strong visual and erotic impact so that they can be said to connote to-be-looked-at-ness. Woman displayed as sexual object is the leitmotif of erotic spectacle: from pin-ups to strip-tease, from Ziegfelt to Busby Berkeley, she holds the look, and plays to and signifies male desire. (Mulvey, 19)

Like Karintha, Fern is an object silenced-subject to a male gaze-but unlike "Karintha," this sketch, if for a moment, lets us hear the woman's voice: "'Doesnt it make you mad?' She meant the row of petty gossiping people. She meant the world" (19). By not introducing Fern's remark according to narrative convention (e.g., "she said") deflects attention from her act of speaking. Additionally, the speaker's insistence on interpreting Fern's words for us ("she meant ... she meant") betrays his wish to ascribe meaning to an otherwise indecipherable woman and thus contain her in a fixed reading. Likewise, we are privy to the speaker's impressions of this woman's singing voice: ". . . she sang, brokenly. A Jewish cantor singing with a broken voice. A child's voice, uncertain, or an old man's" (19). That her voice is depicted as "broken," "uncertain," resembling that of a child or an old man, further emphasizes its frailty and lack of agency. Additionally, the fact that the speaker figures Fern, like Karintha, as a singer underscores her role as siren, an enchantress who lures men to their ruin. As I will show in my next section, as readers we can usefully put these texts in conversation with one another. And while male writers of the Renaissance like Toomer 
relied heavily on older (white) tropes appropriated from timehonored tradition, female writers of the same movement responded, actively and aggressively, to the way in which they were represented in the art of the period.

There is beauty

In the faces of black women,

Jungle beauty

And mystery

Dark hidden beauty

In the faces of black women,

Which only black men

See.

—Edward Silvera, "Jungle Taste"20

Beyond the aesthetic

pleasure one got

from watching her,

she contributed

little, sitting for the

most part silent, an

odd dreaming look in

her hypnotic eyes.

-Nella Larsen, Passing ${ }^{21}$

The wine-flushed, bold-eyed boys, and even the girls,

Devoured her with their eager, passionate gaze ...

-Claude McKay, "Harlem Dancer"22

While Edward Silvera's "Jungle Taste" celebrates the beauty of black women-and in this way validates them-it nonetheless fixes the black male gaze on a female body, boasting that there exists something in black women "which only black men see." The women writers of the Harlem Renaissance take issue with what their male counterparts claim to "see," and Nella Larsen is a case in point. The body of work produced by Larsensome of which was recovered fairly recently-is largely occupied with the imaging of black women in art. As Cheryl Wall points out, Larsen accomplishes many projects under the guise of treating the theme of "passing." 22 I would add to Wall's discussion that Larsen successfully and covertly critiques the way women were visualized in the art of the Harlem Renaissance. For instance, her short story "The Wrong Man" (1926)—while dealing on the surface with a presumably white leisure class reminiscent of Fitzgerald's The Great Gatsby-also concerns the ten- 
sion between the female protagonist's self-fashioning and a man's ability to destroy it: "Julia] had been so happy, so secure, and now this: Ralph Tyler, risen from the past to shatter the happiness which she had grasped for herself" (Larsen, Intimation 5). ${ }^{24}$ We can read this tale as an expression of a black woman's desire to remake herself and the very real concern that this identity might instantly be stripped away through a man's agency. Larsen encourages us to read Julia as a metaphorical female artist; the heroine has in fact attended art school in Chicago, under the patronage of Ralph Tyler, to study interior decorating (5). And Julia, as a stand-in for the woman artist, feels "trapped" (Julia admits to her husband-without disclosing the source of her anxiety-that she feels "small ... futile ... sort of trapped" [5]) similar to the way black women artists felt confined by the limits imposed on them by their status as doubly "othered," i.e., black and female.

So much like other works produced by artists of the Harlem Renaissance, Larsen's oeuvre devotes considerable attention to moments of spectatorship-specifically instances in which the female body is rendered a spectacle. We see this in "The Wrong Man," particularly in the fateful final scene in which Julia reveals her secret to a man she mistakes for Ralph Tyler: "The man looked curiously at the woman sitting so motionless in the summerhouse in the rock garden. Even in the darkness she felt his gaze upon her." (7, emphasis mine). Frequently we see in Larsen-as in her contemporaries-a woman rendered an object of the male gaze and here it is a gaze that paralyzes, rendering the woman "motionless." And the fact that the titular "wrong man" remains nameless-yet fixes Julia (an artist) as the object of his gaze-underscores the idea that Larsen is concerned with a particular type of man given to objectifying and thus denying women agency.

Larsen invites us to read a woman through an objectifying male gaze in the short sketch "Freedom" (1926). Unlike her other works, it is told through a man's perspective. The narrator lays bare this man's objectifying impulses: "His contemptuous mood visualized her at times. . . . He would be conscious of every detail of her appearance: her hair simply arranged, her soft dark eyes, her delicate chin propped on hands rivaling the perfection of La Gioconda's" (Intimation, 15, emphasis mine). Here the woman is valued chiefly for her aesthetic merit. And what's more, Larsen's male gazer likens the woman's hands to pieces of art-specifically those of da Vinci's most famous portrait of a 
lady, the penultimate mystifying, mysterious woman-as-art. ${ }^{25}$ That Larsen adopts a male gaze to liken a woman's hands to those of the Mona Lisa-a lady frozen into art-underscores the idea that female hands are meant, according to a masculine gaze, to be passive objects embodying "perfection," and not active agents of change or creators of art.

While Larsen's Passing, unlike "Freedom," is related through a point of view gendered female - that of protagonist Irene Redfield-the novel successfully exposes the debilitating imaging of black women as objects of a gaze that attempts to master and undo. In fact, I want to suggest that-through the vehicle of a black female gazer with "unseeing eyes" - the author offers a veiled critique of a male gaze that is comparably nearsighted. ${ }^{26}$ Larsen's dedication of Passing to Carl Van Vechten (white literary gatekeeper, writer, and chief photographer of the Renaissance) seems an appropriate gesture, considering his reputation as a literal generator and disseminator of images. As Deborah McDowell argues, Van Vechten in a sense started a trend that contemporary black male authors subsequently followed. His Nigger Heaven (1926) set the stage for a literary tradition of imaging black sexuality (McDowell, xiv). ${ }^{27}$ Thus, Van Vechten laid down a foundation of distorted images of black female sexuality and Claude McKay, in Home to Harlem (1928), picked up where he left off. ${ }^{28}$ Additionally, as McDowell notes, Arna Bontemps's God Sends Sunday (1931) continued the trend of imaging black women as " 'primitive exotic' sex objects" (McDowell xv). So Passing's inscription to Van Vechten-with its "unseeing," untrustworthy gazer Irene-is perhaps Larsen's way of critiquing Van Vechten and his followers through a subtle literary device. ${ }^{29}$

Irene's function as reader-or, more appropriately, misreader-is signaled by the novel's opening scene, in which she literally and metaphorically acts as reader of the beautiful mulatta Clare Kendry. Irene examines a letter from Clare and interprets it as emblematic of this woman; she finds "something mysterious and slightly furtive about it. A thin sly thing ... a a little flaunting" (Larsen, Passing 143). Irene associates Clare with a popular, jaded feminine trope, that of woman-as-feline: "Catlike. Certainly that was the word which best described Clare Kendry" (144). Throughout the course of Larsen's narrative, we are reminded of the critical gap between what Irene "notes"-what she "seemed to see," "what Irene Redfield remembered" - and the reality of Clare Kendry $(143,146)$. By inserting so many qualifiers, Larsen makes clear the vast and 
significant discrepancy between Irene's perception and the truth of the world around her; Irene's glance, like the objectifying male gaze, is one that does not penetrate the surface, and it follows that her reading of Clare is misguided.

The gaze Irene directs at Clare recalls that of the English Renaissance poets, in its efforts to catalog and fragment a woman's beauty; Larsen here appropriates this objectifying lens as a kind of reply to the male poets of the Harlem Renaissance who analogously adopted the habit of the Elizabethans in cataloging female beauty. (For instance, in George Leonard Allen's poem titled "Portrait," the speaker devotes a stanza each to an unnamed woman's "eyes," "cheeks," and "form."30) Similarly, Irene focuses considerable attention on Clare's "peculiar caressing smile," "that wide mouth like a scarlet flower against the ivory of her skin," her "bright lips slightly parted" $(148,155$, 161). Clare's hypersexualized mouth is a repository for desire and is not, it seems-according to Irene's gaze-intended for speaking. Irene's appreciation of Clare's eyes (she deems them "magnificent") indicates that she reads them as objects to be gazed upon-to be admired as precious works of art-and not as themselves active participants in the gaze (161). Rather, her features are, to Irene's mind, "too provocative" for Clare's own $\operatorname{good}(152)$.

Through Irene's objectifying gaze we are encouraged to read Clare as a spectacle that titillates and pleases the eye; she is ascribed considerable aesthetic value. For instance, Irene finds Clare's weeping visually appealing: "few women, [Irene] imagined, wept as attractively as Clare" (196). Larsen is again careful here to temper the assessment with the operative term "imagined," further suggesting that Irene's impressions of Clare are not to be trusted. Larsen's narrator, following Irene's gaze, makes clear the degree to which Irene reads Clare as a spectacle: "Beyond the aesthetic pleasure one got from watching [Clare], she contributed little, sitting for the most part silent, an odd dreaming look in her hypnotic eyes" (209, emphasis mine). Later Irene admits to her husband that she admires Clare for her "decorative qualities" (216). Clare, then, is rendered-through Irene's gaze-an object of conspicuous consumption. ${ }^{31}$

Gwendolyn Bennett and her literary sisters share with Larsen an interest in subverting this gaze that objectifies and denies agency. Bennett's "Street Lamps in Early Spring" glorifies night as a refuge for black women. "Night" is personified as a kind of female spirit: 
Night wears a garment

All velvet soft, all violet blue...

And over her face she draws a veil

As shimmering fine as floating dew ...

And here and there

In the black of her hair

The subtle hands of Night

Move slowly with their gem-starred light. ${ }^{32}$

By draping herself in such a "veil," Night assumes a means to evade the objectifying gaze; symbolically, night becomes a place to which all black women can retreat in an effort to release themselves from an eye that seeks to define them. Maureen Honey identifies this trend in the work of women artists of the Harlem Renaissance:

While women looked to natural settings in general for space in which to savor the freedom from confining roles, night was sought most frequently, as it was a time when the objectifying eye was closed in sleep and the freedom to be at one with the soul could be safely enjoyed. (Honey, 16)

And if we follow Bennett's model, we see that once the female spirit is liberated from the objectifying gazers, then her "subtle hands" too are set free to "[m] ove slowly with their gem-starred light."

The "subtle hands" of female illustrators are altogether absent from Locke's list of credits. His New Negro features visual images produced exclusively by male artists (Winold Reiss, Aaron Douglas, Miguel Covarrubias). The women of the race are, in a sense, represented in this volume. They are depicted in what the text calls "Type Sketches of Negro Women" and the picture captions make no effort to hide this penchant for reading women as types. We might consider, for instance, Reiss's "Ancestral: A Type Study," "From the Tropic Isles," "The Librarian," and "Two Public School Teachers." That Reiss renders the nameless, rather despondent woman profiled in "From the Tropic Isles" handless is suggestive of her lack of agency (figure 5). Significantly, these pictures cast women in traditionally "feminine" roles (e.g., librarian, teacher)-occupations that have been deemed fit for women. Further, the portraits of real women are those who have taken on traditional roles, e.g., educators Mary McLeod Bethune and Elise J. McDougald. Reiss's portraits of McDougald and Bethune (the latter which renders the subject a 


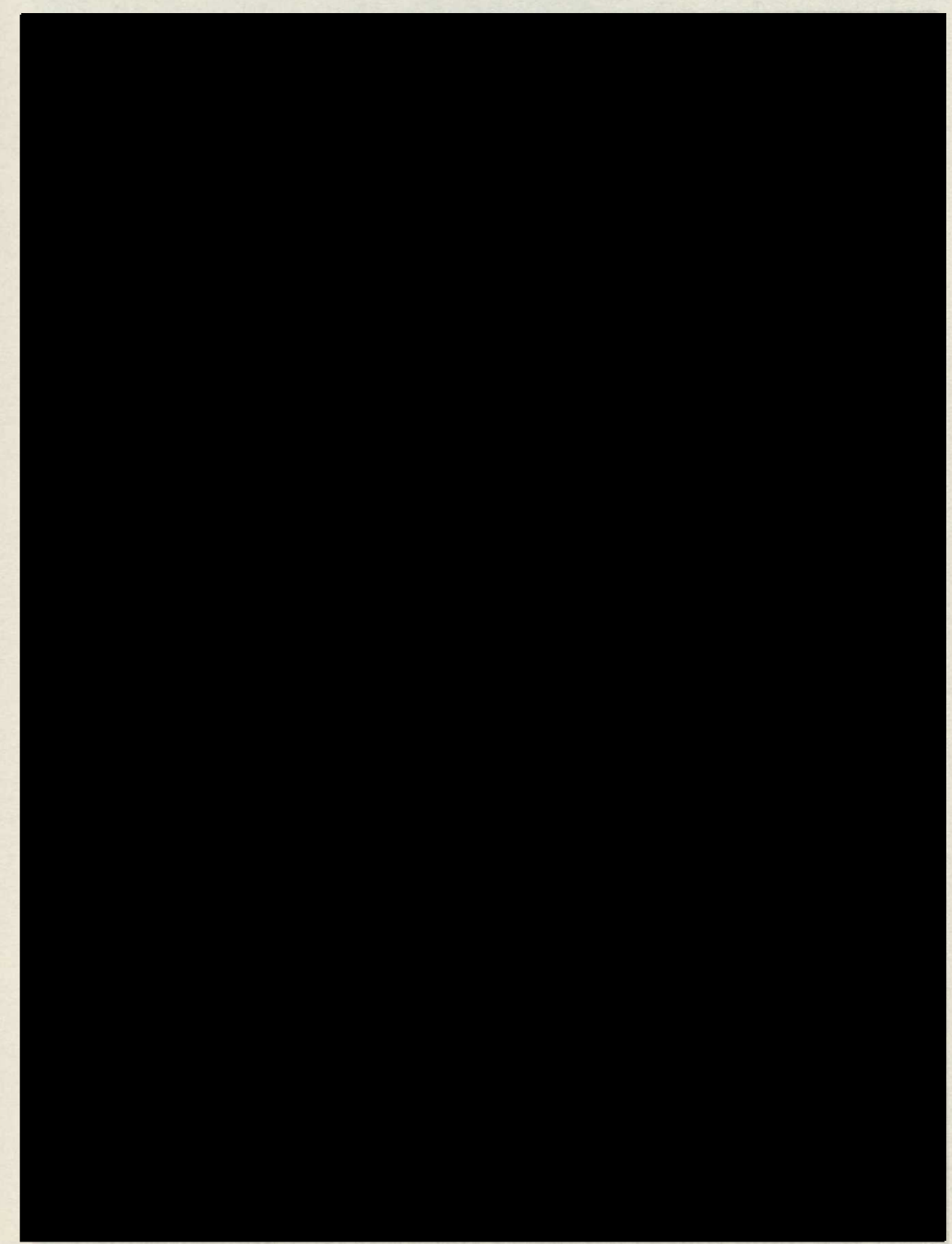

Fig. 5. Winold Reiss, "From the Tropic Isles" for The New Negro, ed. Alain Locke. 
Mammy-esque figure) likewise withhold the woman's hands from our view (figures 6 and 7). These women are not poets, painters, novelists; they are not female artists. Reiss, Douglas, and Covarrubias refrain from devoting their palettes to illustrations of, for instance, Jessie Fauset, Zora Hurston, or Nella Larsen. In effect, these male artists deliver a message to their viewers that the female "types" displayed in Locke's book are the most appropriate models for black women.

While Reiss's portraits of women are quietly relegated to the back pages of Locke's text, his portraits of men of the Harlem Renaissance are, by contrast, prominent and privileged. Alain Locke, Jean Toomer, Charles S. Johnson, Robert Russa Moton, and W. E. B. Du Bois are all portrayed with notable dignity. All are dapperly dressed in sophisticated suits, and, significantly, we can see their hands, which are emblematic of their agency. ${ }^{34}$

Gwendolyn Bennett, a prolific literary and visual artist of the Renaissance, makes similar use of the iconographic significance of hands. Her July 1926 cover of Opportunity, which followed the first printing of Locke's New Negro, features an attractive female jazz dancer (figure 8). The image foregrounds this woman while three silhouetted dancing ladies, framed by African motifs, are figured in the background. All four women use their arms and hands, gesturing with verve, and there is no trace of the angst-or the impending consumption of female bodiesfound in Douglas's "Sahdji." Interestingly, in the rendering of the Madonna and child Bennett produced for the cover of Opportunity's January 1926 issue, the artist positions her Virgin in almost the same pose as her jazz dancer (figure 9). The details of the two images are strikingly similar: the folds of the woman's dress, the outstretched right hand, the slightly elevated left shoulder, the woman's confident smile. The Magi of the January cover anticipate the three dancing figures of the July image. What's more, Bennett depicts the three men such that their gazes are not fixed on the Madonna but instead are cast downward, in a humble gesture; the Virgin's own eyes look out of the portrait, as if to challenge the spectator's gaze. While one of the Virgin's hands supports the newborn Christ child, her other hand-like that of the jazz dancer-seems to reach out in pursuit of something more. It is her right hand that she extends, symbolically the hand that gives rather than receives. By following her image of the Virgin Mary six months later with this voluptuous jazz dancer-whose hands are free and whose eyes suggest she's entranced by her dance (itself an artistic medium)-and by re- 


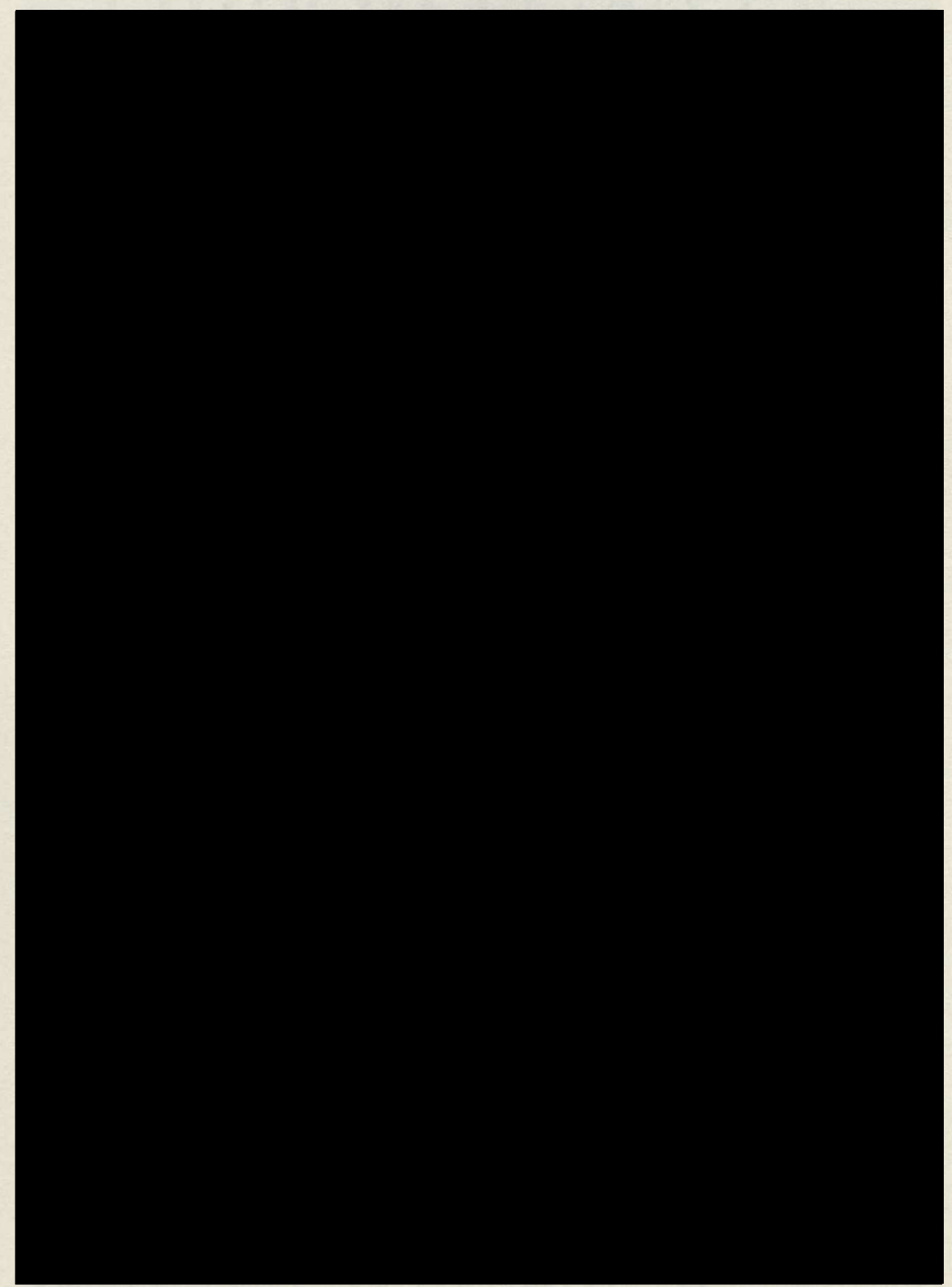

Fig. 6. Winold Reiss, illustration of Mary McLeod Bethune for The New Negro, ed. Alain Locke. 


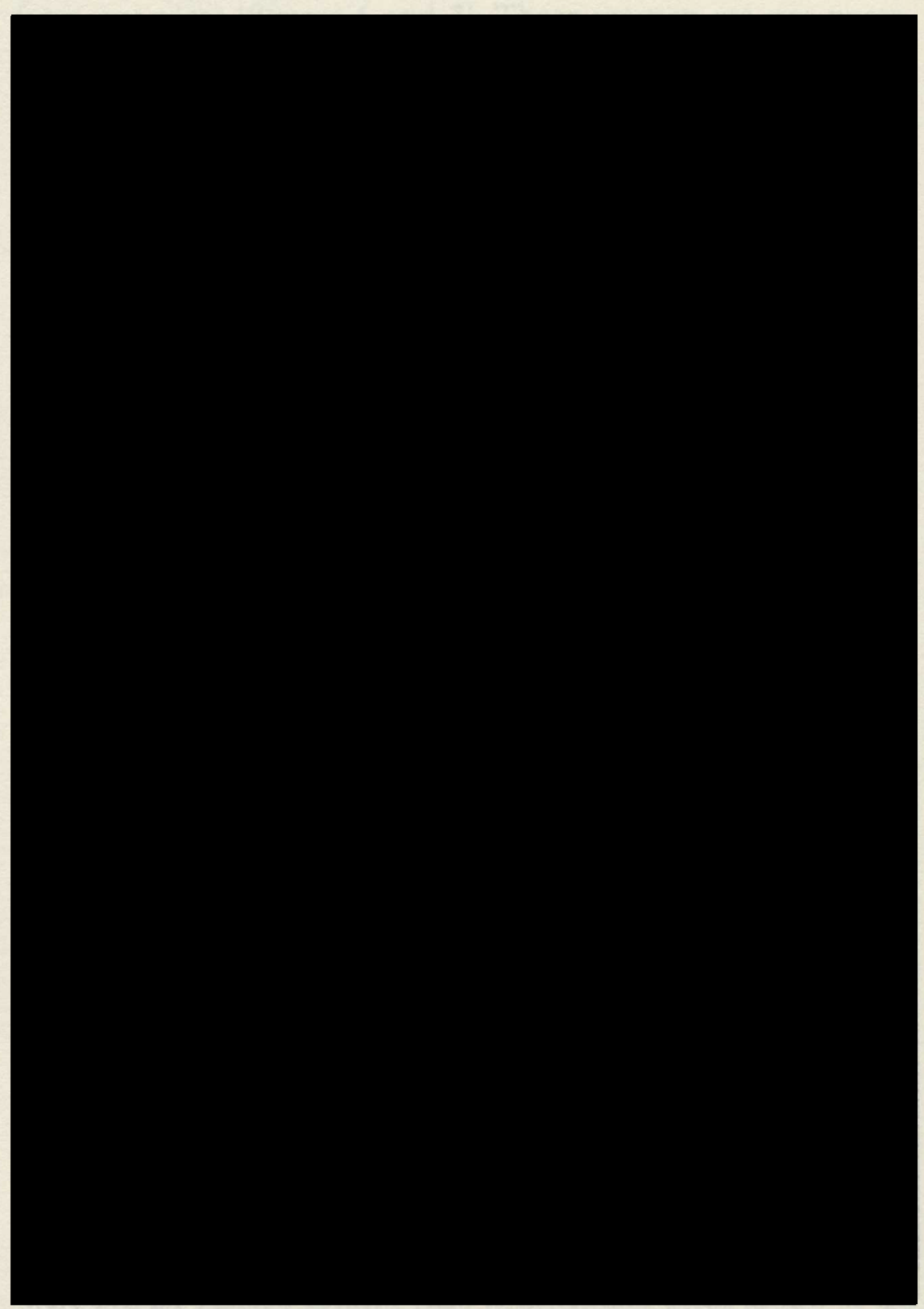

Fig. 7. Winold Reiss, illustration of Elise J. McDougald for The New Negro, ed. Alain Locke. 


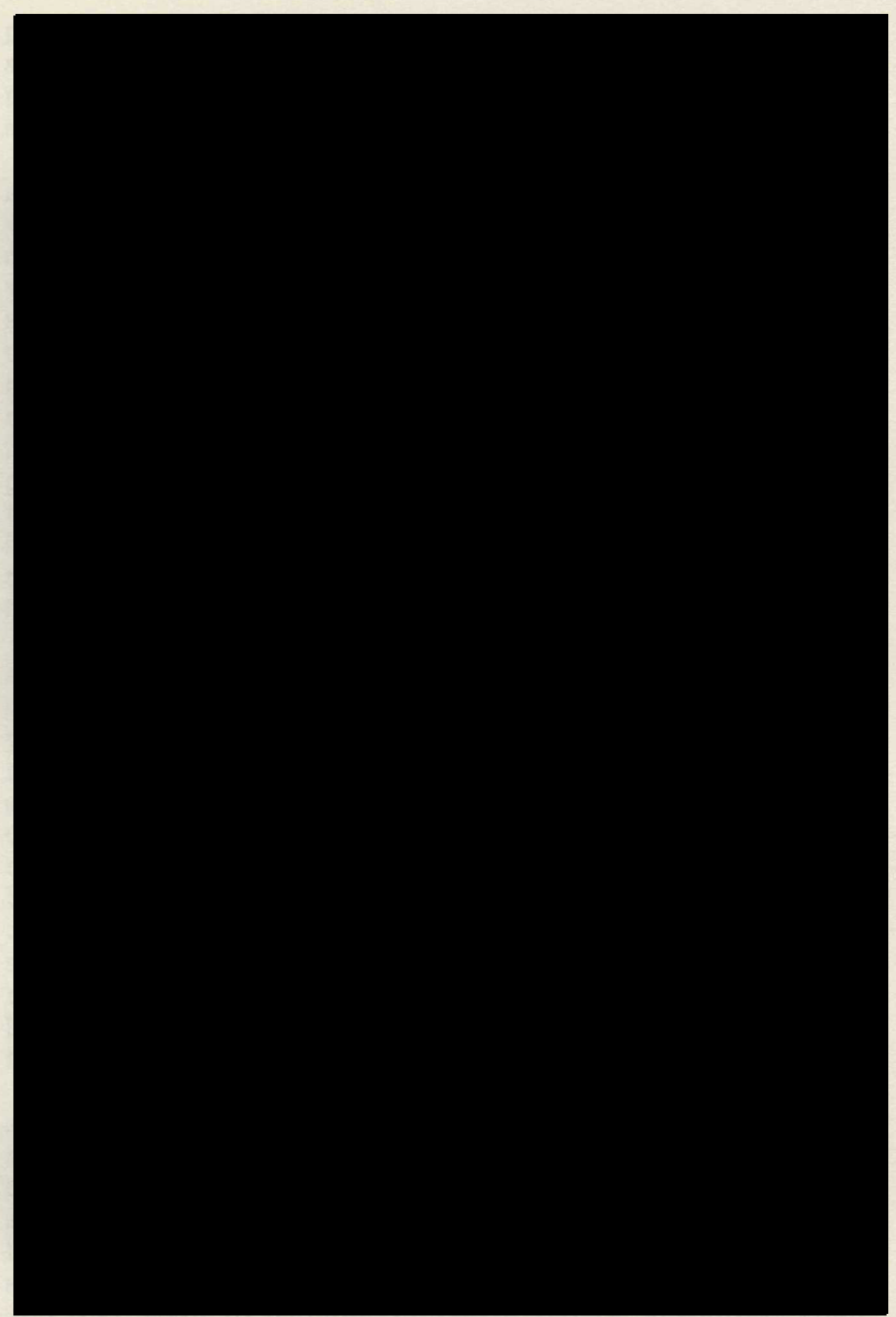

Fig. 8. Gwendolyn Bennett, cover of July 1926 Opportunity, Journal of Negro Life. Photo courtesy of the National Urban League. 


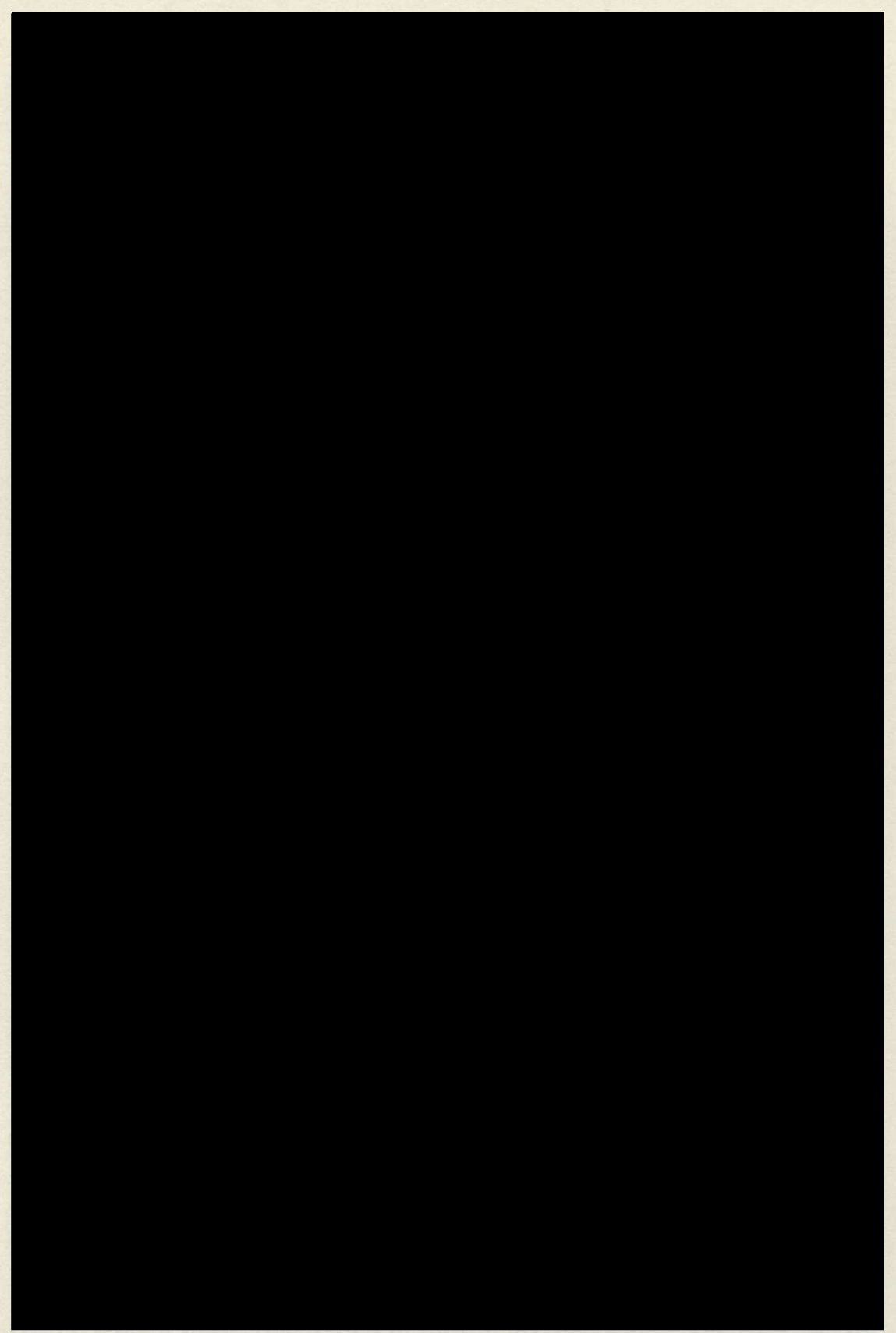

Fig. 9. Gwendolyn Bennett, cover of January 1926 Opportunity, Journal of Negro Life. Photo courtesy of the National Urban League. 
placing the wise men of January with the dancers and beaming sunlight of July, Bennett suggests a kind of "progress" to be made for the black woman-an evolution to a more celebratory, sunny, liberated existence.

The work of Lois Mailou Jones picks up where Bennett's images leave off, with its deliberate reply to the renderings of black women produced by men of the Harlem Renaissance. ${ }^{35} \mathrm{Her}$ art evidences a special capacity for nobly and honorably portraying women at work. Jones's paintings focus on women's hands, showing them engaged in active pursuits. Alain Locke apparently took an interest in Jones's work while both served on the faculty at Howard University. ${ }^{36}$ "Jennie" (1943) has in fact been read as a result of Locke's influence (Bearden, 384). Jones's painting shows a young black woman cleaning fish with dignity and pride (figure 10). I would add that-if this work draws inspiration from Locke-it is fitting the artist privileges the woman's hands as if to serve as a reminder to Locke and his entourage of the important difference and change that can be effected through female agency.

Jones keeps her gaze fixed on hands as representative of agency. Her "Peasant Girl, Haiti" (1954), produced, like "Jennie," well after the close of the Harlem Renaissance, features a young black girl in the marketplace with her wares. The girl's hands are prominent, reflecting her status as an agent, a doer, and not merely an object. Further, her posture suggests both childbirth and sexuality while her hands-protectively poised as they are-imply control over these activities. Jones's "Marché, Haiti" (1963) shows men and women at the marketplace using their hands to carry their goods above their heads-representative of women's part in a metaphorical uplift that suggests racial uplift. Further, the women's eyes in this painting are visibly raised upward, as if looking forward to movement in a positive, promising direction.

These black women artists, then, challenge a tradition that assigns them to types: woman as art, woman as artful, woman as artless, and not woman as artist. Through their literature and their art, they successfully, often subtly, subvert and deconstruct the detrimental images to which their sex has been bound. These women are acutely aware of the New Negro's "unseeing" gaze- one that fixed them as objects without agencyand they want to reclaim their own artistic authority. Their voices echo Mae Cowdery's questions, raised at the start of this essay: "Can you not hear us? . . Can you not see us?" 


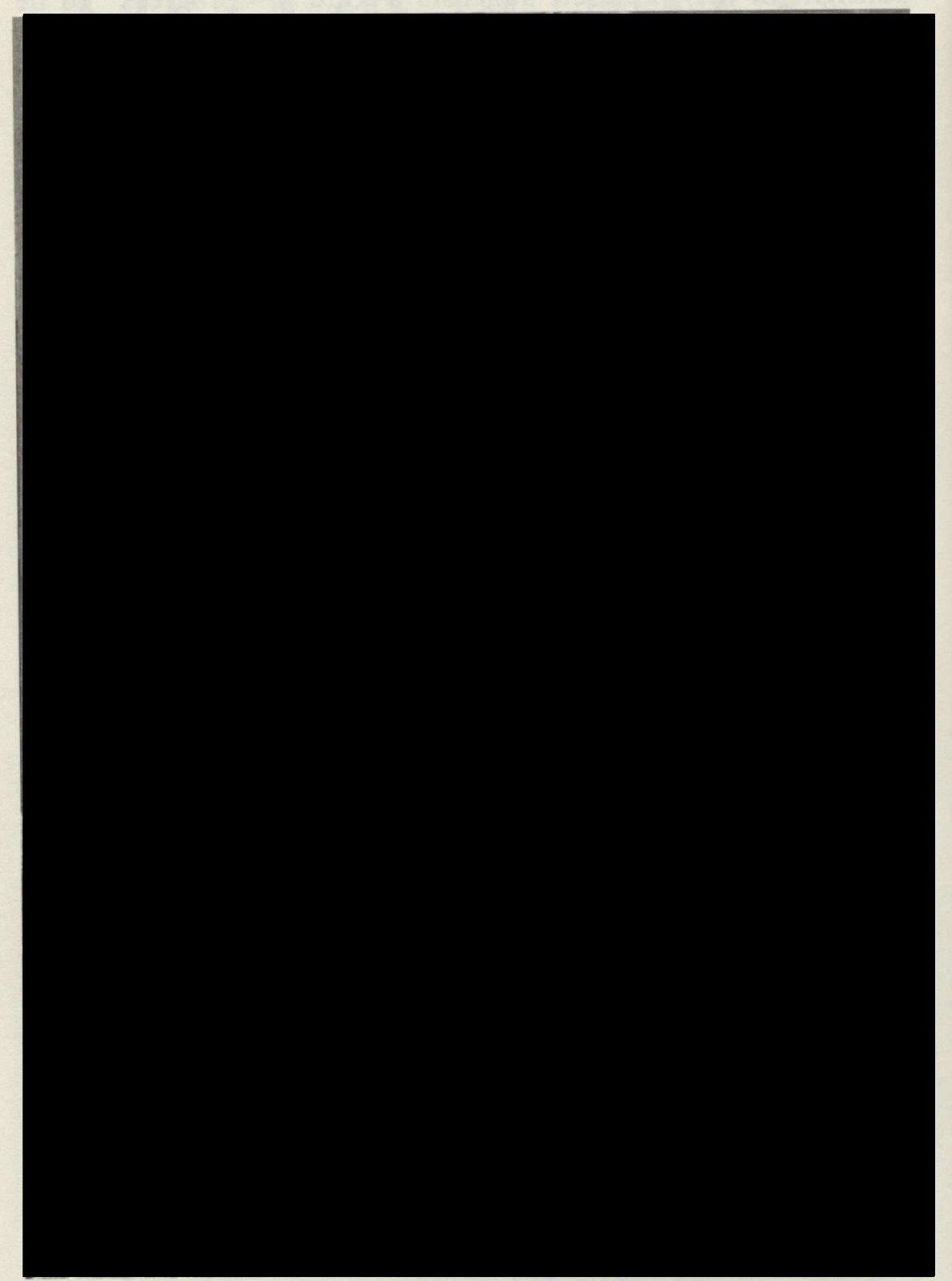

Fig. 10. Lois Mailou Jones, "Jennie," (1943), oil on canvas. Courtesy of the Howard University Gallery of Art, Washington, DC. 
Amy Jacques Garvey responds to these questions and recognizes the "New Negro Woman" and her capacities, possibilities, and responsibilities. ${ }^{37}$ As she understands it, this New Negro Woman is to:

(1) Work on a par with men in the office and the platform; (2) Practice thrift and economy; (3) Teach constructive race doctrine to children; (4) Demand absolute respect of the race from all men; (5) Teach the young to love race first. ${ }^{38}$

All of these duties, of course, are active pursuits-tasks that require the use of women's hands and rely on female agency. There is no room in Amy Garvey's agenda for "feminine Calibans" or "Dark Madonnas of the grave."

Elise Johnson McDougald's "The Task of Negro Womanhood"-laced with such phrases as "fortunately," "heartening," and "there is hope"-radiates a sense of promise and possibility for the "New Negro Woman," notwithstanding the daunting challenges she faces:

We find the Negro woman figuratively struck in the face daily by contempt from the world about her. . . . But through it all, she is courageously standing erect, developing within herself the moral strength to rise above and conquer false attitudes.... The wind of the race's destiny stirs more briskly because of her striving. (McDougald, in Lewis 71, 75)

The literary and artistic daughters of these black womenamong them Alice Walker, Toni Morrison, Paule Marshall, Faith Ringgold-share a devotion to advancing female artistic agency. They join Gwendolyn Bennett in their hopes that the "subtle hands of Night" might be released to "[m]ove slowly with their gem-starred light" and thus be invested with the agency and authority to do their work.

\section{Notes}

1. The literary vehicle of the National Urban League, Opportunity, along with the NAACP's Crisis, served two major functions during the Harlem Renaissance: creative outlet for artists and source of information concerning the "New Negro." I would like to thank Paula Barnes, Maryemma Graham, Tara Hart, Robert S. Levine, Shara McCallum, Jaime Osterman, Catherine Romagnolo, Mary Helen Washington, Australia Tarver, and the University of Maryland Department of English for the generous support and encouragement that 
helped bring this essay to light. I owe a special thanks to Jaime Osterman Alves, trusted friend and reader, for so graciously lending her time, encouragement, and brilliance to this essay's many incarnations.

2. Locke edited the March 1925 edition of Survey Graphic, which took for its theme "Harlem, the Mecca of the New Negro." Albert and Charles Boni expanded the text and published it in book form as The New Negro in December 1925 .

3. I invoke here Martha Banta's use of the term "imaging" in my consideration of the way in which African Americans have been represented as types in American art and culture. (See Martha Banta, Imaging American Women: Idea and Ideals in Cultural History [1987].)

4. Recent scholarship has recognized the limitations of Alain Locke's perspective; he has, for instance, been accused of misogyny. See Gloria T. Hull, Color, Sex, \&) Poetry: Three Women Writers of the Harlem Renaissance (Bloomington: Indiana University Press, 1987) and Thadious M. Davis, Nella Larsen, Novelist of the Harlem Renaissance: A Woman's Life Unveiled (Baton Rouge: Louisiana State University Press, 1994). Venetria K. Patton and Maureen Honey's enlightening collection Double-Take: A Revisionist Harlem Renaissance Anthology (2001) acknowledges The New Negro's shortcomings, citing its "degree of sexism, elitism, and political conservatism" (xxxvii). Interesting and, I think, enlightening, is the revelation by Patton and Honey that Locke was a staunch advocate of art for art's sake: "In an early essay, 'The Colonial Literature of France' (1923), [Locke] argued that the black artist should embrace 'art for its own sake, combined with that stark cult of veracity-the truth whether it hurts or not.' Thus, in editing The New Negro, he sought to show that the new Renaissance writers should create 'art for art's sake,' which distinguished them from the previous wave of African American writers, like Grimke and Fauset, who addressed social issues in their creative work, explicitly using it as a propaganda tool" (xxxv). Locke, then, obviously would have clashed with W. E. B. Du Bois on this score (cf. Du Bois's "Criteria of Negro Art"), but it is also worth noting that an insistence on art devoid of political agenda can often be to the detriment of those who are subject to oppression social, political, racial, and sexual.

5. The breadth of this project compels me to sacrifice in-depth analysis of particular texts in the interest of examining the larger picture. While a few critics have treated the women of the Harlem Renaissance-most notably Maureen Honey, Venetria K. Patton, Gloria Hull, and Cheryl Wall-there is not to date a satisfactory study of the imaging of black women in the visual and literary art of this period. And while in their teaching and scholarship Hazel Carby, Carla L. Peterson, and Mary Helen Washington have recognized the extent to which black women have been inadequately addressed by feminist criticism, my goal is to examine how a supposedly liberating cultural movement-the Harlem Renaissance-in fact contained black women in particularly limited roles.

6. We might consider, for instance, the prevalence of Carl Van Vechten's photographs, the rise of cubism and other modernist art forms, the emergence of film as artistic medium, and the prominence of the flapper as spectacle.

7. Winold Reiss was in fact Aaron Douglas's mentor and teacher.

8. As several critics have shown, over a hundred women writers were generating material from cultural centers in and outside Harlem in the 1920s and 1930s (Lorraine E. Roses and Ruth E. Randolph, Harlem Renaissance and Be- 
yond: Literary Biographies of 100 Black Women Writers, 1900-1945 [Boston: G. K. Hall, 1990] xxiii). Erlene Stetson makes the important point that black women writers of this movement have been grossly neglected because "[d]escriptions of the massive oppressions that [black women] have experienced do not support the white myths of American life" (qtd. in Roses, xxiv). More recently, Venetria K. Patton and Maureen Honey in Double-Take have made it their goal to "even out the disadvantages of gender that kept black women from publishing books as widely as their male peers" $(\mathrm{xx})$. Patton and Honey elaborate on the source of those disadvantages: "the system of patronage operating during the Harlem Renaissance privileged men. As a result, it was harder for most women to get the financial and professional support they needed to get into print" (xxiv). Scholars who have unearthed the work of many of these black women writers include Gloria Hull, Mary Helen Washington, Ann Allen Shockley, and, more recently, Patton and Honey.

9. The black Madonna is also one of the emblems of the Garvey movement, which sought to instill in working-class blacks a "sense of self-worth, racial dignity, and a dream of a new society in Africa" (Paula Giddings, When and Where I Enter: The Impact of Black Women on Race and Sex in America [New York: William Morrow \& Co., Inc., 1984] 193). Garvey's "African Orthodox Church featured icons of a Virgin Mother who was black and a Satan who was white" (Giddings, 193).

10. Published in The Crisis, October 1922; the poem is elsewhere identified as "Black Woman" (David Levering Lewis's The Portable Harlem Renaissance Reader and Dictionary of Literary Biography). Such a dual classification underscores the inextricable link between motherhood and black women and the problematic assumptions therein.

11. Elise Johnson McDougald enhances Georgia Douglas Johnson's realistic vision of motherhood. In "The Task of Negro Womanhood" (1925), McDougald paints a portrait of "the modern Negro mother" whose "burden is twofold," as she works out of the home while struggling to raise children, often alone: "If the mothers of the race should ever be honored by state or federal legislation, the artist's imagination will find a more inspiring subject in the modern Negro mother-self-directed but as loyal and tender as the much extolled, yet pitiable black mammy of slavery days." (McDougald, "The Task of Negro Womanhood," The Portable Harlem Renaissance Reader, ed. David Levering Lewis [New York: Penguin, 1994] 70.)

12. Cullen, Color, 4. Cullen's poem begs comparison to Shakespeare's Sonnet 130, in which the speaker validates his dark mistress: "And yet, by heaven, I think my love as rare / As any she belied with false compare."

13. Bronfen, 117. I want to note here that Bronfen's valuable, sweeping study does not discuss the frequency with which black female bodies were turning up dead in the art and literature of the Harlem Renaissance.

14. James Weldon Johnson's "Go Down Death: A Funeral Sermon" also projects the image of the Dark Madonna of the grave. As we saw in Brown and Cullen, the woman (here "Sister Caroline") has already lost her life by the start of the poem. Notwithstanding the consolation that "She is not dead; ... She's only just gone home ... she's resting in the bosom of Jesus," the woman is in fact dead, transformed into an object whose eyes are "closed," eternally subjected to our gaze. (James Weldon Johnson, "Go Down Death: A Funeral Sermon," The Portable Harlem Renaissance Reader, ed. David Levering Lewis [New York: Penguin, 1994] 284.) 
15. For another example of the feminine Caliban stereotype, see Wallace Thurman's "Cordelia the Crude" (1926), a first-person narration of an encounter with a young Harlem prostitute; the text was recenty reprinted, with an accompanying illustration by Richard Bruce (Nugent) in Patton and Honey, Double-Take. I would like to thank Catherine Romagnolo for the insight she lent to my reading of Douglas's "Sahdji."

16. As Carla L. Peterson has explained in her work, an especially damaging stereotype attached to black women is the tragic mulatta, a white feminist abolitionist construction. The antebellum tragic mulatta plot is marked by the following features: the mulatta is sexualized, objectified; she is seduced; she is the daughter of her master; she is burdened with the weight of a dark secret; she inevitably dies. (See, for example, Peterson's discussions of Frances E. W. Harper's Iola Leroy, especially "'Further Liftings of the Veil': Gender, Class, and Labor in Frances E. W. Harper's Iola Leroy" in Listening to Silences: New Essays in Feminist Criticism. ed. Elaine Hedges and Shelley Fisher Fishkin [New York: Oxford University Press, 1994].)

17. Cf. Hughes's "Jazzonia," which appears on the opposite page: "Were Eve's eyes / In the first garden / Just a bit too bold? / Was Cleopatra gorgeous / In a gown of gold?" (Langston Hughes, "Jazzonia," The New Negro: An Interpretation, ed. Alain Locke [New York: Albert and Charles Boni, Inc., 1927] 226.

18. Laura Mulvey, Visual and Other Pleasures (Bloomington: Indiana University Press, 1989) 13. While Mulvey's discussion concerns narrative film, her study is applicable to works of the Harlem Renaissance in the way in which they anticipate and borrow from film's conventions.

19. Toomer, 19.

20. Edward Silvera, "Jungle Taste," in Cullen, Caroling Dusk, 214.

21. Nella Larsen, Passing, in Quicksand and Passing. (New Brunswick, N.J.: Rutgers University Press, 1986) 209.

22. McKay, "Harlem Dancer," in Lewis, 296.

23. According to Wall, Larsen's Passing (1929) "breaks with literary conventions of passing and the tragic mulatta.... Using the tragic mulatta as a cover, [Larsen] set forth a vision far more complex and daring than even her most enthusiastic critics imagined" (Cheryl Wall, Women of the Harlem Renaissance [Bloomington: Indiana University Press, 1995] 138).

24. The fact that the term "color" and "hue" are strewn about this story, which is inaugurated by the phrase "The room blazed with color," suggests that "The Wrong Man" concerns issues attending women of color (Nella Larsen, An Intimation of Things Distant: the Collected Fiction of Nella Larsen, ed. Charles R. Larson [New York: Anchor Books, 1992] 3).

25. In "Freedom," Larsen seems to invoke a short story by Edith Wharton (whose work Larsen knew and admired) in her comparison to the hand of the Mona Lisa. Wharton's "The House of the Dead Hand" (1904), which similarly makes use of the trope of the hand to represent women's failed agency, describes a painting of a woman whose left hand "recalls the hand of the Mona Lisa" (Edith Wharton, Collected Short Stories of Edith Wharton, volume 1, edited by R. W. B. Lewis [New York: Charles Scribner's Sons, 1987] 513). Further, Larsen's decision to use a male reflector echoes Wharton's favorite choice of narrative perspective for her short stories.

26. Larsen, Passing, 218. Larsen's work, especially Passing, suggests the author shared something of a literary kinship with Edith Wharton. The Age of Innocence (1920), for instance, presents us with a similarly unreliable gazer, in 
the person of Newland Archer, whose eyes also are described as "unseeing." I have argued elsewhere that Wharton uses her Archer as a device to critique the imaging of American women ("Rereading Wharton's 'Poor Archer': A Mr. 'Might-have-been' in The Age of Innocence," American Literary Realism, Winter 1998.) Larsen applies an analogously myopic lens (that of Irene Redfield) to call into question the imaging of black women in art. Further, Georgia Douglas Johnson in "Let Me Not Lose My Dream" points to "eyes unseeing," which belies an awareness of a kind of myopic perspective in the art and literature of the Renaissance.

27. Van Vechten's novel, set in jazz-age Harlem, draws its name from the theater balcony to which African Americans were relegated: "That's what Harlem is, ... we sit in our places in the gallery ... and watch the white world sitting down below us in the good seats" (qtd. in Benet, Reader's Encyclopedia of American Literature, ed. George Perkins et al, New York: HarperCollins, 1991).

28. See, for instance, McKay's portraits of women, namely Felice (prostitute) and Congo Rose (nightclub entertainer). McKay's women generally are sexualized and imaged as pieces of art. In a typical scene, Jake reads a woman as "a breathing statue of burnished bronze"; others, "[w]ith their arresting poses and gestures, their deep shining painted eyes, ... resembled the wonderfully beautiful pictures of women of ancient Egypt" (Claude McKay, Home to Harlem [Boston: Northeastern University Press, 1987] 105).

29. I acknowledge the complex nature of Larsen's connection to Van Vechten: she was a devoted friend and admiring mentee who made clear her debt to him for helping publish her first novel, Quicksand (1928). At the same time, it is likely she was sensitive to his depiction of the black race and black women in particular. In Passing, the figure of Hugh Wentworth, an obvious stand-in for Van Vechten, joins in on imaging Clare Kendry through an objectifying gaze-his, of course, being a specifically white male gaze; at the "Negro Welfare League" dance, Wentworth inquires about Clare's origins by asking about "the blonde beauty out of the fairy-tale" (Larsen, Quicksand and Passing. [New Brunswick, N.J.: Rutgers University Press, 1986] 205). Clare, then, is read as an idealized Sleeping Beauty type, a passive trope for visual pleasure.

30. George Leonard Allen, "Portrait," Opportunity, January 1927, 15.

31. Thorstein Veblen in The Theory of the Leisure Class (1899), his study of fin-de-siècle American culture, coins the term "conspicuous consumption" to describe the habit of buying costly items that serve no function but to demonstrate the exorbitant wealth of the owner. Irene plays the role of conspicuous consumer (spectator) while positioning Clare as that which is conspicuously consumed (spectacle).

32. Opportunity, May 1926.

33. What McDougald refers to as "the grotesque Aunt Jemimas of the streetcar advertisements, [which] proclaim only an ability to serve" (Elise Johnson McDougald, "Task of Negro Womanhood," in David Levering Lewis, ed. The Portable Harlem Renaissance Reader [New York: Penguin, 1994] 69).

34. A notable exception is Reiss's portrait of Paul Robeson. While in Robeson's portrait (as "Emperor Jones"), the subject's hands are not featured, Locke's positioning of this image, placing it in the midst of Jessie Fauset's "A Gift of Laughter," has the effect of an interruption. Robeson, with his smirklike grin and diverted eyes, has a menacing presence, giving the impression of intruding upon Fauset's discourse-as if to metaphorically cut off her voice. In 
Reiss's image of Cullen, neither the man's body nor his hands are featured; it is simply a study of the subject's head.

35. Jones enjoyed a lengthy, prolific career as a twentieth-century artist and teacher whose work has made a difference. Studying painting in 1930s Paris, Jones "made a transition from work that was modeled after the French Impressionist and Post-Impressionist painters to work that is abstract, modern, and African-influenced" (Romare Bearden, A History of African-American Artists: From 1792 to the Present [New York: Pantheon Books, 1993] 388).

36. Locke suggested that Jones portray her own people as well as the French landscapes inspired by her time in Paris (Romare Bearden, 384).

37. Second wife of Marcus Garvey, leader of the Universal Negro Improvement Association (UNIA). 194.

38. Amy Jacques Garvey, rpt. in Paula Giddings, When and Where I Enter,

\section{Works Cited}

Bearden, Romare. A History of African-American Artists: From 1792 to the Present. New York: Pantheon Books, 1993.

Bonner, Marita. Frye Street $\oplus$ Environs: The Collected Works of Marita Bonner. Edited by Joyce Flynn and Joyce Occomy Stricklin. Boston: Beacon Press.

Bronfen, Elisabeth. Over Her Dead Body: Death, Femininity and the Aesthetic. New York: Routledge, 1992.

Cullen, Countee, ed. Caroling Dusk: An Anthology of Verse by Negro Poets. New York: Harper \& Brothers, 1927.

Color. New York: Harper \& Brothers, 1925.

Davis, Thadious M. Nella Larsen, Novelist of the Harlem Renaissance: A Woman's Life Unveiled. Baton Rouge: Louisiana State University Press, 1994.

Giddings, Paula. When and Where I Enter: The Impact of Black Women on Race and Sex in America. New York: William Morrow \& Co., Inc., 1984.

Honey, Maureen, ed. Shadowed Dreams: Women's Poetry of the Harlem Renaissance. New Brunswick, N.J.: Rutgers University Press, 1989.

Hull, Gloria T. Color, Sex, et Poetry: Three Women Writers of the Harlem Renaissance. Bloomington: Indiana University Press, 1987.

Larsen, Nella. An Intimation of Things Distant: The Collected Fiction of Nella Larsen. Edited by Charles R. Larson. New York: Anchor Books, 1992.

- Quicksand and Passing. New Brunswick, N.J.: Rutgers University Press, 1986.

Lewis, David Levering, ed. The Portable Harlem Renaissance Reader. New York: Penguin, 1994.

Locke, Alain, ed. The New Negro: An Interpretation. 1925. Reprint, New York: Albert and Charles Boni, Inc., 1927.

McDowell, Deborah E., introduction to Quicksand and Passing by Nella Larsen. New Brunswick, N.J.: Rutgers University Press, 1986. 
Mulvey, Laura. Visual and Other Pleasures. Bloomington: Indiana University Press, 1989.

Patton, Venetria K., and Maureen Honey. Double-Take: A Revisionist Harlem Renaissance Anthology. New Brunswick, N.J.: Rutgers University Press, 2001.

Roses, Lorraine E., and Ruth E. Randolph. Harlem Renaissance and Beyond: Literary Biographies of 100 Black Women Writers, 1900-1945. Boston: G. K. Hall, 1990.

Toomer, Jean. Cane. Edited by Darwin T. Turner. New York: W. W. Norton, 1988.

Van Der Zee, James, Owen Dodson, and Camille Billops. The Harlem Book of the Dead. Dobbs Ferry, N.Y.: Morgan \& Morgan, 1978.

Wall, Cheryl. Women of the Harlem Renaissance. Bloomington: Indiana University Press, 1995.

Washington, Mary Helen. Black-Eyed Susans: Classic Stories By and About Black Women. New York: Anchor Books, 1975.

. "Black Women Image-Makers." Black World. 13 August 1974: 10-18.

Invented Lives: Narratives of Black Women, 1860-1960. Garden City, N.Y.: Doubleday, 1987. 